\title{
A Novel p.K116Q SNP in the OLR1 Gene and Its Relation to Fecundity in Awassi Ewes
}

Mohammed M. Mohammed

Al-Qasim Green University

Tahreer Mohammed Al-Thuwaini ( $\nabla$ tahreermohammed@ymail.com )

Al-Qasim Green University https://orcid.org/0000-0003-4534-2963

Mohammed Baqur S. Al-Shuhaib

Al-Qasim Green University

\section{Research}

Keywords: Litter size, OLR1, polymorphism, sheep

Posted Date: September 13th, 2021

DOI: https://doi.org/10.21203/rs.3.rs-832411/v1

License: (a) (1) This work is licensed under a Creative Commons Attribution 4.0 International License. Read Full License

Version of Record: A version of this preprint was published at Theriogenology on March 1st, 2022. See the published version at https://doi.org/10.1016/j.theriogenology.2022.03.014. 


\section{Abstract}

Background

Sheep's fecundity is determined by both twinning rate and litter size, both influenced by several genes, one of which is $O L R 1$ (oxidized low-density lipoprotein receptor gene). This study aimed to determine the genetic variation of the $O L R 1$ gene affecting the fecundity traits of Awassi ewes.

Results

Two genotypes of 334-bp amplicons, CC and CA were detected. In a sequence reaction, the novel mutation p.K116Q was discovered in CA genotypes. There was a highly significant $(P \leq 0.01)$ association between the single nucleotide polymorphism (SNP) and reproductive traits, in that sheep with the p.K116Q SNP had lower litter size, twinning rate, fecundity, and lambing percentages than individuals with CC genotypes. The ewes with CC genotypes had 1.98 lambs more than those with CA genotypes. These observations imply that the missense P.K116Q variant has an adverse effect on the traits under study.

\section{Conclusions}

As such, SNP p.K116Q appears to negatively influence fecundity traits in Awassi sheep. The data evidence that the OLR1 gene variant is one of the most important candidates for marker-assisted selection in the sheep industry.

\section{Background}

The fecundity in sheep flocks is an important determinant of profitability [1]. A sheep's fecundity is determined by twinning rate and litter size, which are affected by many different genes [2]. One of these is the oxidized low-density lipoprotein receptor gene (OLR1) [3] that resides in chromosome 3 in sheep and contains 6 exons (Adopted from ncbi.nlm.nih.gov); in chromosome 5 in cattle with 5 exons [4]. This gene encodes OLR1 protein and belongs to the C-type lectin family that functions to absorb and degrade low-density lipoproteins [5], which impacts energy balance, in turn influencing reproductive characteristics [3]. It is also possible that this encoded protein functions to regulate fecundity genes so that the OLR1 gene is involved in sheep fecundity [2].

Several studies have been reported the polymorphism of the OLR1 gene in livestock and its relationship to phenotypic traits. An SNP within the exon and intron regions of the $O L R 1$ gene is associated with phenotypic traits in cattle, according to Komisarek and Dorynek [6] and Fonseca et al. [7]. Furthermore, OLR1 is regarded as a potentially important gene in dairy cattle growth traits $[8,9]$. The 3 ' untranslated regions of $O L R 1$ (NW_215807: g. 8238C $>A$ ) contain a polymorphism associated with the fat content of milk [10]. Besides, the SNP in the bovine OLR1 gene (c. $495 \mathrm{~T}>\mathrm{C}$ ) affects carcass traits, fat accumulation, and growth in Angus, Charolais, and hybrid cattle [11]. The OLR gene is investigated in another study conducted on Dutch Holsteins/Friesians; the results indicated that $O L R$ g. $8232 \mathrm{C}>\mathrm{A}$ significantly affected $(\mathrm{P}<0.05)$ the fat content of milk [12]. A genetic variant in buffalo $O L R 1$ at position 8,232 in the 3'-UTR has been affected by fat content and yield in the Mehsana breed [13]. Additionally, Javed et al. [14] provided evidence of the association between the polymorphisms of the $O L R 1$ gene and growth traits, as well as dairy quality parameters in buffalo. The A/C SNP in the 3'-UTR fragment of the OLR1 gene has been linked to lactational traits in Iranian Holstein cattle [15]. According to a recent study, the bovine OLR1 T10588C and T10647T mutations have significant associations with fat distribution, back fat thickness, and intramuscular fat accumulation [16]. Additionally, there is a relationship between OLR1 gene genetic polymorphism and litter size in Xidu black pigs. The TT genotype exhibited significantly larger litter sizes in comparison to TC and CC genotypes ( $P<$ 0.01), indicating that the 7-bp mutation $\mathrm{T} / \mathrm{C}$ at intron 4 had a significant effect on litter size traits [17]. Considering the aforementioned studies, there has been little research conducted on the impact of genetic polymorphisms in the $O L R 1$ gene on fecundity traits in livestock, and no research on their association with fecundity traits in Awassi sheep.

\section{Methods}

\section{Animal}

Two hundred mature ewes (114 with single progeny and 86 with twins) were used in this study, not pregnant or lactating, and aged between 2.5 and 5 years. Two herding stations (Babylon and Karbala, Iraq) were randomly selected to receive the animals. For the entire year, both grass and concentrated food (2.5 percent of their body weight every day, composed of barley, bran, salt (59\%), (40\%) and (1\%) concentrates, respectively), as well as freshwater, were provided to the animals. Several fecundity traits were recorded at the stations, 
such as twinning rate, lambing percentage, and litter size. Litter size was determined by dividing the number of lambs born by the number of ewes lambing.

\section{DNA and PCR}

In the morning, before feeding the sheep, blood samples were drawn from the jugular vein. A vacutainer tube containing EDTA was used to collect blood for genetic analysis. To extract genomic DNA, a rapid salting-out technique was employed [18]. The amplification of three different regions of the genetic code of OLR1 was achieved using NCBI Primer-BLAST [19], provided by Bioneer (South Korea). A PCR experiment was conducted using Bioneer's PCR premix $(50 \mu \mathrm{M}, 10 \mathrm{mM}, 30 \mathrm{mM}, 1.5 \mathrm{mM}$ for dNTPs, Tris- $\mathrm{HCl}, \mathrm{KCl}, \mathrm{MgCl} 2$, and $1 \mathrm{U}$ Top DNA polymerase). Using the thermal gradient device (Eppendorf, Germany), the best PCR amplification conditions were determined (Table 1). The denaturation was carried out for 4 minutes at $94{ }^{\circ} \mathrm{C}$, followed by 30 cycles of denaturation for 30 seconds, annealing for 45 seconds, and elongation for 30 seconds. Accordingly, the results were verified by electrophoresis of PCR products on agarose gels (1.5\%) and determining the gel image with a Chemidoc Gel Imager (Bio-Rad, USA).

\section{SSCP (single-strand conformation polymorphism)}

All PCR products were genotyped according to the protocol of Imran et al. [20]. The denaturing-loading buffer (95\%, formamide, 0.05\% xylene cyanol, and 20 mM EDTA, pH 8) was added to equal volumes for each PCR amplicon. Following 7 minutes of denaturation, the PCR amplicons were transferred onto wet ice and stored for 10 minutes. Using a 0.5 TBE buffer, samples denatured in neutral polyacrylamide gels were loaded on. Subsequently, the gels were electrophoresed for 4 hours at 200mA and $100 \mathrm{~V}$ at room temperature. To stain the gels, the rapid staining protocol developed by Byun et al. [21] was used.

\section{DNA sequencing and in silico analyses}

Following the detection of SSCP bands in polyacrylamide gels, downstream reactions were performed using the methods of sequencing laboratories (Macrogen, Geumchen, Korea). A referring sequence of the OLR1 gene was retrieved from NCBI's website (https://www.ncbi.nlm.nih.gov). A BioEdit ver, 7.1. was used to edit DNA polymorphisms within each detected genotype (DNASTAR, Madison) and visualized using SnapGene Viewer ver. 4.0.4 (http://www.snapgene.com). Amino acid reading frames were detected using the Expasy software [22]. Moreover, a comparison of amino acid sequences was conducted, using UniProtKB, with their corresponding sequences in the OLR1 database (http://www.uniprot.org/align/). Many computational tools were used to predict the structure and function of mutant proteins, including SIFT [23], PolyPhen-2 [24], Provean [25], Panther [26], and PhD SNP [27].

\section{Statistical analyses}

Genotype and allele frequency were analyzed by PopGen32, version 1.31 [28]. Using Hardy-Weinberg disequilibrium law, disequilibrium was calculated. According to Botstein et al. [29], polymorphism information content (PIC) was computed. Association analysis of the OLR1 genotypes was performed using IBM SPSS 23.0 (NY, USA), with a general linear model as follows:

$Y_{i j k l}=\mu+G_{i}+P_{j}+A_{k}+e_{i j k l}$

Where: $\mathrm{Y}_{i j k l}=$ phenotype characteristics, $\mu=$ the mean of all traits, $G_{i}=$ fixed effect of $i^{\text {th }}$ genotypes $(i=\mathrm{CC}, \mathrm{AC}, \mathrm{AA}) P_{j}=$ fixed effect of $j^{\text {th }}$ parity $(j=1,2,3,4), A_{k}=$ fixed effect of $k^{\text {th }}$ age group (2.5,>2.5-3.5,>3.5-4.5,>4.5-5), and $\mathrm{e}_{i j k l}=$ random residual error. Tukey-Krammer tests were performed to examine differences between means with a level of significance of $(P \leq 0.05)$. Reproductive traits of fecundity (the number of lambs weaned per ewe), lambing percentage (the number of lambs born per ewe lambed), and ewe birth type were analyzed using Chi-square test. Based on preliminary analysis, effects of interaction and lambing season were unaffected by the model findings and were excluded.

\section{Results}

\section{Genotyping of OLR1 gene}

The PCR amplification of three genetic fragments of $334 \mathrm{bp}, 291 \mathrm{bp}$, and $274 \mathrm{bp}$ was performed on the 3 OLR1 coding regions, along with their flanking regions (Fig. 1, A). Although the 291 bp amplification of exon 4 by PCR was designed, PCR experiments turned out to be problematic since agarose gels showed no specific bands. Following this, PCR-SSCP patterns were designed to cover exon 6 exhibited monomorphic electrophoretic migration and no heterogeneity was observed. Furthermore, two distinctive PCR-SSCP patterns 
were observed in the $334 \mathrm{bp}$ amplicons designed for exon 3 (Fig. 1, B). The sequencing results showed that only one of the SSCP variants carried the C246A SNP, indicating exon 3 heterogeneity. Based on the C246A substitution, the detected SSCP variants were given genotypic values CC for homozygous C/C SSCP variants and CA for heterozygous C/A SSCP variants present at position 246 of

PCR amplicons (Fig. 1, C). The Expasy software indicated that a missense (p.K116Q) occurred at the $116^{\text {th }}$ position of the mature OLR1, where lysine (Lys) was exchanged with glutamine (Glu) (Fig. 1, D). Regarding the genetic diversity of p.K116Q, the genotype CA was predominant with a total frequency of $0.75(n=149)$ and a lower prevalence for the genotype CC with a total frequency of $0.25(n=51)$ (Table 2). However, the Chi-square test showed that polymorphism in the OLR1 gene at the K116Q SNP locus deviated significantly from the HWE $(P \leq 0.05)$.

\section{In silico prediction of p.K116Q}

All used in silico prediction tools were given neutral/non-deleterious signals for $\mathrm{p.K116Q}$. The I-Mutant 2 tool further confirmed that the p.K112Q SNP does not function deleteriously, as it predicted increased stability of OLR1 upon modification of this SNP (Table 3). This non-deleterious effect on the structure, function, and stability of the analyzed protein may be attributed to the noncritical positions that it occupies on the OLR1 protein.

\section{OLR1 gene analysis: statistical results}

As such, based on the association analysis of p.K116Q SNP locus with fecundity traits, individuals with CA genotype had significantly $(P \leq 0.01)$ lower litter size, twinning rate, fecundity, and lambing percentage than individuals with CC genotype (Table 4). In comparison to that of CA genotype ewes, CC ewes had 1.98 lambs. Hence, the missense P.K116Q SNP had a negative impact on these traits.

\section{Discussion}

\section{Polymorphism of $O L R 1$ gene and genetic diversity}

The genetic diversity analysis of the OLR1 gene in Awassi ewes revealed that genotype CA was predominant with a total frequency of $0.75(n=149)$ and a lower prevalence for the genotype CC with a total frequency of $0.25(n=51)$. However, the Chi-square test showed that polymorphism in the OLR1 gene at the K116Q SNP locus deviated significantly from the HWE $(P \leq 0.05)$. Numerous studies have reported polymorphisms in the $O L R 1$ gene in livestock in various regions. In direct genomic sequencing of $O L R 1$, Khatib et al. [8] identified 3 genotypes CC, AC, and AA in Holstein Dairy Cattle with 3'-UTR polymorphism. Using Pstl/PCR-RFLP, Komisarek and Dorynek [6] identified 3 genotypes of OLR1 in Polish Holstein-Friesian bulls CC, CT, and TT. Further, Javed et al. [14] revealed the polymorphism in exonic regions of the $O L R 1$ in Nili Ravi buffalo and determined 3 genotypes $A A, A B$ and BB. Furthermore, a single nucleotide polymorphism (SNP) in the promoter region of the $O L R 1$ gene (c. $-495 \mathrm{~T}>\mathrm{C}$ ) in hybrid, Angus, and Charolais beef cattle is identified and assigned CC, CT, and TT genotypes [11]. Fonseca et al. [7] genotyped rs109019599 in OLR1 by PCR-RFLP assays and observed in the agarose gel AA (254 bp), CC (269 bp), and AC (269 and 254 bp). Moreover, the identification of OLR1 genotypes in the 3'UTR region of dairy cattle is performed using PCR-RFLP, i.e., AA, AC and CC genotypes [3]. Recently, Anggraeni [4] identified the base mutations of the OLR1 gene at 3'UTR location by PCR-RFLP techniques in Holstein Friesian dairy cattle and found 3 genotypes $\mathrm{CC}, \mathrm{AC}$, and AA. The aforementioned studies indicated that no studies have been undertaken on OLR1 genotyping in Awassi sheep. Therefore, this study provides genotypic information and new associations that may prove more useful in selecting sheep and be recommended for measuring functional traits in future marker-assisted selection programs.

\section{Sequencing and in silico analyses of OLR1 gene}

By detecting the C246A SNP in only one of the SSCP mutations, a sequencing reaction confirmed the presence of heterogeneity in exon 3 (Fig. 1, C). A p.K116Q SNP was positioned in the $116^{\text {th }}$ lysine residue of the mature OLR1, where an amino acid substitution occurred from lysine (Lys) to glutamine (Glu) (Fig. 1, D). Some SNPs occur in non-coding regions, whereas others in coding regions [30]. These non-synonymous SNPs modify amino acid sequences when present in a coding sequence (called mutant SNPs), altering protein activity and causing drastic phenotypic changes [31,32]. The missense mutation can negatively impact function not only by changing the protein's stability but also by interfering with the structure and function of other biological molecules [33]. Additionally, missense mutations can affect a molecule's flexibility and alter its equilibrium or alter the dynamics of its conformation [34]. All the in silico prediction tools used in the current study provided neutral or non-deleted signals for p.K116Q (Table 3). This non-deleterious effect in terms of the structural, functional, and structural stability of the analyzed protein occurs due to its non-critical positions where occupied 
in this protein. Studer et al. [35] note that mutations can change an organism's phenotype in any way, perhaps with a beneficial, detrimental or neutral effect on its fitness.

\section{Association analyses of $O L R 1$ gene with fecundity traits}

This study examined the association between $\mathrm{p}$. K116Q SNP locus and fecundity traits and revealed that individuals with AC genotype had significantly $(P \leq 0.01)$ lower litter size, twinning rate, fecundity, and lambing percentage compared to CC genotypes (Table 4$)$. As a result, these traits were negatively affected by C246A SNP mutation. In this regard, only one article has addressed the potential association between polymorphisms in the porcine $O L R 1$ gene and litter size. This study showed a $T / C$ mutation at $7 \mathrm{bp}$ of intron4 with 3 genotypes TT, TC, and CC. The litter size of TT genotyped piglets is significantly higher than that of TC and CC genotyped piglets [36].

Importantly, the OLR1 degrades the oxidized forms of low-density lipoproteins (ox-LDL) and promotes cholesterol accumulation and adipocyte fatty acid uptake, thereby affecting liver fat metabolism [3,6]. Although these roles are significant, changes in the lipid profile or fat content could lead to clinical and physiological problems [37]. Thus, by upregulating OLR1, adipocytes increase their total cholesterol content and capacity to absorb free fatty acids (FFA). If the adipocyte's lipid storage capacity is exceeded, it becomes unable to control the release of FFAs into the blood circulation, ultimately resulting in abnormal accumulation of lipid outside the adipocyte [38]. Moreover, excess fatty acids in the ovary generate damage to the cumulus and granulosa cells responsible for normal steroidogenesis in the gonads [39]. Furthermore, the accumulation of intracellular lipids causes high levels of free fatty acids to form, leading to oxidative damage and the production of highly active oxidative metabolites that cause irreversible cellular damage [40]. It has been shown that these metabolic changes can damage oocytes directly or by affecting their follicular environment [41]. Based on these data, OLR1 gene variation causes several damaging aspects on oocytes, which could adversely affect fecundity traits. Consequently, the Awassi breed is characterized by a high level of adaptability to harsh environments [42] with a lower reproductive capacity [43, 44]. The low reproductive rate of this breed is a major concern for many breeders in the Middle East. Further, the low prevalence of the CC genotype with a total frequency of $0.25(n=51)$ in this study is likely to be one of several factors contributing to the low fertility of the Awassi breed.

\section{Conclusion}

A novel single nucleotide polymorphism (SNP), p. K116Q, was found in the OLR1 gene (exon 3), in the heterozygous CA genotype. The results of the association analysis between $\mathrm{p}$. K116Q SNP locus and fecundity traits revealed that individuals with the CA genotype had significantly lower litter sizes, ewe birth types, fecundity, and lambing percentages than those with the CC genotype. Twin-producing ewes with CC genotypes showed more measured fecundity traits than single-producing ewes with CC genotypes. In light of these results, $O L R 1$ is a promising candidate gene for sheep marker selection.

\section{Declarations}

\section{Acknowledgements}

In acknowledging the sheep stations (Babylon and Karbala) that provided the Awassi ewes, the authors express their gratitude.

\section{Author contribution}

Tahreer M. Al-Thuwaini: Conceptualization, writing-original draft, supervision, methodology (lead). Mohammed Baqur S. Al-Shuhaib: Editing, data curation, and investigation (lead). Mohammed M. Mohammed: Methodology (equal).

\section{Data and model availability statement}

None of the data were deposited in an official repository but data are available upon request.

\section{Ethics approval}

With approval no. 020,7,18 provided by Al-Qasim Green University, this study was conducted from July 2020 to March 2021 and followed the international guidelines for the veterinary care and use of livestock.

\section{Consent for publication}


Not applicable.

\section{Conflict of interest statement}

None.

\section{References}

1. Richards JS, Ren YA, Candelaria N, Adams JE, Rajkovic A. Ovarian follicular theca cell recruitment, differentiation, and impact on fertility: 2017 update. Endocrine reviews. 2018; 39(1): 1-20. https://doi.org/10.1210/er.2017-00164

2. Miao X, Luo Q, Zhao H, Qin X. Ovarian transcriptomic study reveals the differential regulation of miRNAs and IncRNAs related to fecundity in different sheep. Scientific reports. 2016; 6(1): 1-11. https://doi.org/10.1038/srep35299

3. Kowalewska-Łuczak I, Czerniawska-Piątkowska E. Polymorphism in the OLR1 gene and functional traits of dairy cattle. Veterinarski arhiv. 2018; 88(2): 171-177. https://doi.org/10.24099/vet.arhiv.170228

4. Anggraeni A. Genetic polymorphisms of the $O L R 1$ and DGAT1 genes associated with milk components in Holstein Friesian dairy cattle under an intensive management in Central Java. In IOP Conference Series: Earth and Environmental Science (Vol. 287, No. 1, p. 012001). IOP Publishing. 2019. https://doi.org/ 10.1088/1755-1315/287/1/012001

5. Mentrup T, Cabrera-Cabrera F, Schröder B. Proteolytic Regulation of the Lectin-Like Oxidized Lipoprotein Receptor LOX-1. Frontiers in Cardiovascular Medicine. 2021; 7: 409. https://doi.org/10.3389/fcvm.2020.594441

6. Komisarek J, Dorynek Z. Effect of ABCG2, PPARGC1A, OLR1 and SCD1 gene polymorphism on estimated breeding values for functional and production traits in Polish Holstein-Friesian bulls. Journal of applied genetics. 2009; 50(2): 125-132. https://doi.org/10.1007/BF03195663

7. Fonseca PDDS, de Souza FR, de Camargo GM, Gil FM, Cardoso DF, Zetouni L, et al. Association of ADIPOQ, OLR1 and PPARGC1A gene polymorphisms with growth and carcass traits in Nelore cattle. Meta gene. 2015; 4: 1-7. https://doi.org/10.1016/j.mgene.2015.02.001

8. Khatib H, Leonard SD, Schutzkus V, Luo W, Chang YM. Association of the OLR1 gene with milk composition in Holstein dairy cattle. Journal of dairy science. 2006; 89(5): 1753-1760. https://doi.org/10.3168/jds.S0022-0302(06)72243-3

9. Rezaei M, Rahbar R, Naderi Y. ABCG2 and OLR1 gene polymorphism on production traits in Holsteins and Simmental cows of Mazandaran Province. Acta Biol. Indica. 2016; 5: 30-37.

10. Wang X, Peñagaricano F, Tal-Stein R, Lipkin E, Khatib H. Association of an OLR1 polymorphism with milk production traits in the Israeli Holstein population. Journal of dairy science. 2012; 95(3): 1565-1567. https://doi.org/10.3168/jds.2011-5012

11. Vinsky M, Islam K, Chen L, Li C. Association analyses of a single nucleotide polymorphism in the promoter of OLR1 with growth, feed efficiency, fat deposition, and carcass merit traits in hybrid, Angus and Charolais beef cattle. Canadian Journal of Animal Science. 2013; 93(2): 193-197. https://doi.org/10.4141/cjas2012-115

12. Soltani-Ghombavani M, Ansari-Mahyari S, Edriss MA. Association of a polymorphism in the 3 'untranslated region of the $O L R 1$ gene with milk fat and protein in dairy cows. Archives Animal Breeding. 2013; 56(1): 328-334. https://doi.org/10.7482/0003-9438-56-032

13. Manisha D, Rank DN, Vataliya PH, Joshi CG. Oxidized low density lipoprotein receptor 1 (OLR1) gene polymorphism in Mehsana buffaloes (Bubalus bubalis). Buffalo Bulletin. 2013; 32(4): 260-264.

14. Javed M, Babar ME, Nadeem A, Yaqub T, Hussain T. Identification of Single Nucleotide Polymorphisms in OLR1 Gene in Nili Ravi Buffalo. Editorial Board. 2013; 701.

15. Hosseinpour Mashhadi M. A research on association between SCD1 and OLR1 genes and milk production traits in Iranian Holstein dairy cattle. Iranian Journal of Applied Animal Science. 2017; 7(2): 243-248.

16. Gui LS, Raza SHA, Jia J. Analysis of the oxidized low density lipoprotein receptor 1 gene as a potential marker for carcass quality traits in Qinchuan cattle. Asian-Australasian journal of animal sciences. 2019; 32(1): 58. https://doi.org/10.5713/ajas.18.0079

17. Mu QIAO, Kang-chi LI, Jun-jing WU, Hua-yu WU, Jia-wei ZHOU, Shu-qi MEl, et al. Polymorphism of porcine OLR1 gene and its association with liter size trait of Xidu black pigs. Hubei Agricultural Sciences. 2020; 59(24): 141.

18. Al-Shuhaib MBS. A Universal, rapid, and inexpensive method for genomic DNA isolation from the whole blood of mammals and birds. J. Genet. 2017; 96(1): 171-176. https://doi.org/10.1007/s12041-017-0750-6 
19. Ye J, Coulouris G, Zaretskaya I, Cutcutache I, Rozen S, Madden T. Primer-BLAST: A tool to design target-specific primers for polymerase chain reaction. BMC Bioinformatics. 2012; 13: 134. https://doi.org/10.1186/1471-2105-13-134

20. Imran FS, Al-Thuwaini TM, Al-Shuhaib MBS, Lepretre F. A Novel Missense Single Nucleotide Polymorphism in the GREM1 Gene is Highly Associated with Higher Reproductive Traits in Awassi Sheep. Biochemical Genetics. 2020; 1-15. https://doi.org/10.1007/s10528-020-10006-x

21. Byun SO, Fang Q, Zhou H, Hickford JGH. An effective method for silver-staining DNA in large numbers of polyacrylamide gels. Anal. Biochem. 2009; 385: 174-175. https://doi.org/ 10.1016/j.ab.2008.10.024

22. Gasteiger E, Gattiker A, Hoogland C, Ivanyi I, Appel RD, Bairoch A. ExPASy: the proteomics server for in-depth protein knowledge and analysis. Nucleic Acids Res. 2003; 31: 3784-3788. https://doi.org/10.1093/nar/gkg563

23. Pauline CN, Steven H. SIFT predicting amino acid changes that affect protein function. Nucl. Acids Res. 2003; 31:38123814. https://doi.org/10.1093/nar/gkg509

24. Adzhubei I, Jordan DM, Sunyaev SR. Predicting functional effect of human missense mutations using PolyPhen-2. Current protocols in human genetics. 2013); 76(1): 7-20. https://doi.org/10.1002/0471142905.hg0720s76

25. Choi Y, Sims GE, Murphy S, Miller JR, Chan AP. Predicting the functional effect of amino acid substitutions and indels. PLOS ONE. 2012; 7: e46688. https://doi.org/10.1371/journal.pone.0046688

26. Tang H, Thomas PD. PANTHER-PSEP: predicting disease-causing genetic variants using position-specific evolutionary preservation Bioinformatics. 2016; 32: 2230-2. https://doi.org/10.1093/bioinformatics/btw222

27. Capriotti E, Calabrese R, Casadio R. Predicting the insurgence of human genetic diseases associated to single point protein mutations with support vector machines and evolutionary information. Bioinformatics. 2006; 22(22): 2729-

2734. https://doi.org/10.1093/bioinformatics/bt/423

28. Yeh FC, Yang RC. POPGENE version 1.31, Microsoft window-based freeware for population genetic analysis. University of Alberta and Tim Boyle, Centre for International Forestry Research, 1999.

29. Botstein D, White RL, Skolnick M, Davis RW. Construction of a genetic linkage map in man using restriction fragment length polymorphisms. American journal of human genetics. 1980; 32(3): 314.

30. Hrdlickova B, de Almeida RC, Borek Z, Withoff S. Genetic variation in the non-coding genome: Involvement of micro-RNAs and long non-coding RNAs in disease. Biochimica et Biophysica Acta (BBA)-Molecular Basis of Disease. 2014; 1842(10): 1910-1922. https://doi.org/10.1016/j.bbadis.2014.03.011

31. Ng PC, Henikoff S. Predicting the effects of amino acid substitutions on protein function. Annu. Rev. Genomics Hum. Genet. 2006; 7: 61-80. https://doi.org/10.1146/annurev.genom. 7.080505.115630

32. Chu D, Wei L. Nonsynonymous, synonymous and nonsense mutations in human cancer-related genes undergo stronger purifying selections than expectation. BMC cancer. 2019; 19(1): 1-12. https://doi.org/10.1186/s12885-019-5572-x

33. Pandurangan AP, Blundell TL. Prediction of impacts of mutations on protein structure and interactions: SDM, a statistical approach, and mCSM, using machine learning. Protein Science. 2020; 29(1): 247-257. https://doi.org/10.1002/pro.3774

34. Stefl S, Nishi H, Petukh M, Panchenko AR, Alexov E. Molecular mechanisms of disease-causing missense mutations. Journal of molecular biology. 2013; 425(21): 3919-3936. https://doi.org/10.1016/j.jmb.2013.07.014

35. Studer RA, Dessailly BH, Orengo CA. Residue mutations and their impact on protein structure and function: detecting beneficial and pathogenic changes. Biochemical journal. 2013; 449(3): 581-594. https://doi.org/10.1042/BJ20121221

36. Qiao M, Li KC, Wu JJ, Wu HY, Zhou JW, Mei SQ, et al. Polymorphism of porcine OLR1 gene and its association with liter size trait of Xidu black pigs. Hubei Agricultural Sciences. 2020; 59(24): 141.

37. Khaki Z, Khazraiinia P, Chegini S, Nia SK. Comparative study of serum lipid profile in chicken, ostrich, cattle, and sheep. Comparative Clinical Pathology. 2012; 21(3): 259-263. https://doi.org/10.1007/s00580-010-1088-0

38. Chui PC, Guan HP, Lehrke M, Lazar MA. PPARy regulates adipocyte cholesterol metabolism via oxidized LDL receptor 1 . The Journal of clinical investigation. 2005; 115(8): 2244-2256. https://doi.org/10.1172/JCl24130

39. Raviv S, Hantisteanu S, Sharon SM, Atzmon Y, Michaeli M, Shalom-Paz E. Lipid droplets in granulosa cells are correlated with reduced pregnancy rates. Journal of ovarian research. 2020; 13(1): 1-10. https://doi.org/10.1186/s13048-019-0606-1

40. Mu YM, Yanase T, Nishi Y, Tanaka A, Saito M, Jin CH, et al. Saturated FFAs, palmitic acid and stearic acid, induce apoptosis in human granulosa cells. Endocrinology. 2001; 142(8): 3590-3597. https://doi.org/10.1210/endo.142.8.8293 
41. Wathes DC, Fenwick M, Cheng Z, Bourne N, Llewellyn S, Morris DG, et al. Influence of negative energy balance on cyclicity and fertility in the high producing dairy cow. Theriogenology. 2007; 68: S232-S241. https://doi.org/10.1016/j.theriogenology. 2007.04.006

42. Al-Thuwaini TM. The relationship of hematological parameters with adaptation and reproduction in sheep; A review study. Iraqi Journal of Veterinary Sciences. 2021; 35(3): 575-580. https://doi.org/10.33899/ijvs.2020.127253.1490

43. Galal S, Gürsoy O, Shaat I. Awassi sheep as a genetic resource and efforts for their genetic improvement-A review. Small Ruminant Research. 2008; 79(2-3): 99-108. https://doi.org/10.1016/j.smallrumres.2008.07.018

44. Gootwine E. Mini review: breeding Awassi and Assaf sheep for diverse management conditions. Tropical animal health and production. 2011; 43(7): 1289-1296. https://doi.org/10.1007/s11250-011-9852-y

\section{Tables}

Table 1. The oligonucleotide primer sets designed for the amplification of the ovine OLR1 gene. The symbols "F" and "R" refer to forward and reverse primers, respectively. The design was based on the ovine NCBI Reference Sequence NC_040254.1.

\begin{tabular}{|c|c|c|c|c|c|c|}
\hline \multirow[t]{2}{*}{ Primer code } & \multirow[t]{2}{*}{ Locus } & \multirow[t]{2}{*}{ Sequence (5】 - 3】) } & \multicolumn{2}{|c|}{$\begin{array}{l}\text { Binding coordinate in the } \\
\text { genome }\end{array}$} & \multirow[t]{2}{*}{$\begin{array}{l}\text { Amplicon } \\
\text { length }\end{array}$} & \multirow[t]{2}{*}{$\begin{array}{l}\text { Annealing } \\
\text { temperature }\end{array}$} \\
\hline & & & Start & Stop & & \\
\hline $\begin{array}{l}\text { OLR1,exo3- } \\
\mathrm{F}\end{array}$ & $\begin{array}{l}\text { Exon } \\
3\end{array}$ & TTCACCGAAATCCAGTGGAGG & 220107792 & 220107812 & $334 \mathrm{bp}$ & $60.4^{\circ} \mathrm{C}$ \\
\hline $\begin{array}{l}\text { OLR1,exo3- } \\
\mathrm{R}\end{array}$ & & ССТСТСGСССТСАTACСTGA & 220108106 & 220108125 & & \\
\hline $\begin{array}{l}\text { OLR1,exo4- } \\
\mathrm{F}\end{array}$ & $\begin{array}{l}\text { Exon } \\
4\end{array}$ & AGAGATGGCATGCATGTGGG & 220113177 & 220113196 & 291 bp & $N A^{*}$ \\
\hline $\begin{array}{l}\text { OLR1,exo4- } \\
\mathrm{R}\end{array}$ & & AATCCAGCCTGACACATCCC & 220113448 & 220113467 & & \\
\hline $\begin{array}{l}\text { OLR1-exo6- } \\
\mathrm{F}\end{array}$ & $\begin{array}{l}\text { Exon } \\
6\end{array}$ & СCCTGCCTGCAGGTTTAGAA & 220114431 & 220114450 & 274 bp & $59.1^{\circ} \mathrm{C}$ \\
\hline $\begin{array}{l}\text { OLR1-exo6- } \\
\mathrm{R}\end{array}$ & & CTAGTAGCAGGCAGTTCCCG & 220114685 & 220114704 & & \\
\hline
\end{tabular}

* No specific results were obtained from utilizing this primers' pair to amplify this locus since no specific bands ( 291 bp) were observed in agarose gel electrophoresis.

Table 2. Genetic diversity of the OLR1 gene in Awassi ewes.

\begin{tabular}{|llllllllllll|}
\hline \multicolumn{2}{|l}{ Observed genotypes } & \multicolumn{2}{ll}{ Genotype frequencies } & \multicolumn{2}{ll}{ Allele frequencies } & Ho & He & Ne & PIC & $\chi^{2}$ \\
\hline CC & CA & CC & CA & A & C & & & & & \\
\hline$n=51$ & $n=149$ & 0.25 & 0.75 & 0.63 & 0.37 & 0.74 & 0.47 & 1.87 & 0.35 & 69.93 \\
\hline
\end{tabular}

Abbreviations: $\chi^{2}$ - Chi-square, Ho - observed heterozygosity, He- Expected heterozygosity, Ne- effective allele frequency, $n$ number of individuals. All Chi-square tests have one degree of freedom and within the significance level $\mathrm{P} \leq 0.05$.

Table 3. The in silico prediction of p.K116Q on ovine OLR1 protein, in terms of structure and function.

\begin{tabular}{|llllllllllll|l|}
\hline SIFT & & \multicolumn{3}{l}{ Meta-SNP } & \multicolumn{2}{l}{ PROVEAN } & SNAP & \multicolumn{2}{ll}{ PhD-SNP } & I-Mutant2 \\
\hline Score & Prediction & Score & Prediction & Score & Prediction & Score & Prediction & Score & Prediction & Score & Prediction \\
\hline 0.130 & Neutral & 0.147 & Neutral & -0.97 & Neutral & 0.260 & Neutral & 0.153 & Neutral & 1.44 & Increase \\
\hline
\end{tabular}

SIFT: Value > 0.05 mutation is predicted neutral; Meta-SNP: Value < 0.5 mutation is predicted neutral; PROVEAN: value > -2.5 is predicted neutral; SNAP: Value < 0.5 mutation is predicted neutral; PhD-SNP: Value < 0.5 mutation is predicted neutral; I-Mutant2: DDG > 0 
increase stability.

Table 4. The association between $O L R 1$ genetic polymorphism at locus $\mathrm{p} .116 \mathrm{~K}>\mathrm{Q}$ and fecundity traits in Awassi ewes.

\begin{tabular}{|c|c|c|c|c|c|}
\hline \multirow[t]{2}{*}{ Genotypes } & \multirow{2}{*}{$\begin{array}{l}\text { Litter size } \\
(\text { LSM } \pm \text { SE) }\end{array}$} & \multicolumn{2}{|c|}{ Ewe birth type (\% ) } & \multirow[t]{2}{*}{ Fecundity } & \multirow[t]{2}{*}{ Lambing percentage } \\
\hline & & Singleton & Twin & & \\
\hline $\mathrm{CC}(51)$ & $1.98 \pm 0.04^{\mathrm{a}}$ & $12(23.52 \%)^{b}$ & $39(76.47 \%)^{a}$ & $1.76^{a}$ & $176.47^{a}$ \\
\hline CA (149) & $1.42 \pm 0.05^{b}$ & $102(68.45 \%)^{a}$ & $47(31.54 \%)^{b}$ & $1.31^{b}$ & $131.54^{b}$ \\
\hline Pvalue & $0.01 *$ & $0.01 *$ & $0.04 *$ & $0.02 *$ & $0.03 *$ \\
\hline
\end{tabular}

$\mathrm{LSM} \pm \mathrm{SE}$, Least square means \pm Standard error, * $(\mathrm{P} \leq 0.05) .{ }^{\mathrm{a}, \mathrm{b}}$ Significant differences in means represent by differences in the same column within each classification.

\section{Figures}

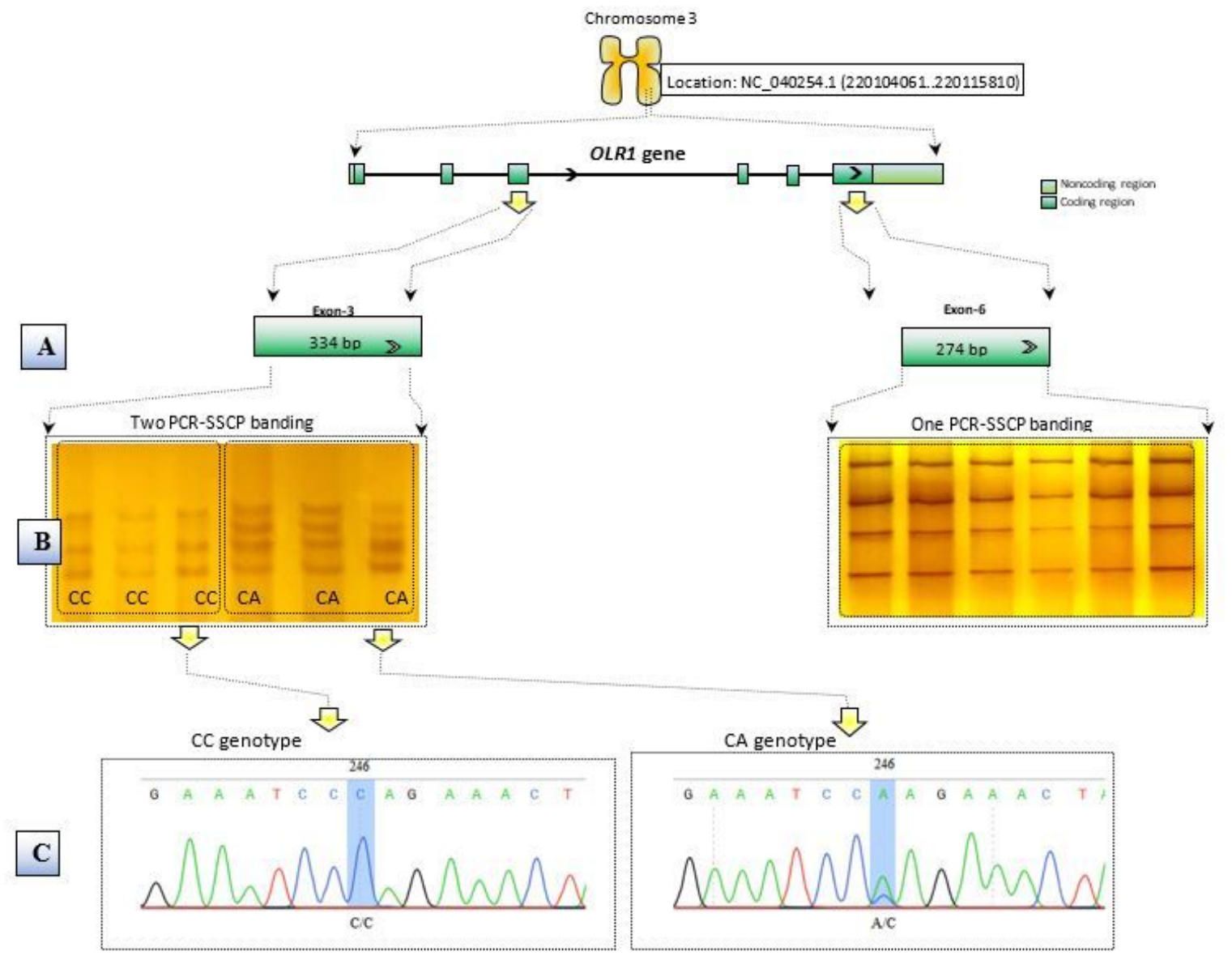

Figure 1

An overview of the OLR1 gene-based PCR-SSCP-sequencing method in Awassi ewes. A) Design of two distinct PCR primer pairs encoding sequences measuring 334 and 274 bases respectively within exon 3 and exon 6 . B) Only one exon 3 was identified as homozygous and heterozygous based on PCR-SSCP genotyping. C) Electropherograms of DNA sequencing data showing that one SNP, C246A, was located in a heterozygous CA genotype at exon 3. 